\title{
23. LITHOLOGY OF THE UPPER GAS HYDRATE ZONE, BLAKE OUTER RIDGE: A LINK BETWEEN DIATOMS, POROSITY, AND GAS HYDRATE
}

\author{
Lisa M. Kraemer, ${ }^{2}$ Robert M. Owen, ${ }^{2}$ and Gerald R. Dickens ${ }^{3}$
}

\begin{abstract}
Gas hydrate on the crest of the Blake Ridge is concentrated over two depth zones: between 185 and 260 mbsf, and between 380 and $450 \mathrm{mbsf}$. Although the abundance of hydrate in the lower zone may be explained by methane cycling across the phase boundary between free gas bubbles and gas hydrate, the upper zone lacks a satisfactory explanation. Chemical analyses of sediment samples from Hole $994 \mathrm{C}\left(31^{\circ} 47.139^{\prime} \mathrm{N}, 75^{\circ} 32.753^{\prime} \mathrm{W}\right)$ were performed to determine if the relatively high hydrate accumulation between 185 and 260 mbsf coincides with an observable change in sediment composition and microporosity. Our analyses indicate a distinct change in lithology across the upper hydrate zone: the carbonate content decreases from about $25 \%$ to about $8 \%$ with a corresponding increase in siliceous microfossils and bulk porosity. An increase in the abundance of siliceous microfossils increases the size and roundness of pore spaces. Large and round pores should provide nucleation sites for gas hydrate that are uninhibited by capillary forces between grains. Upward advecting fluids that are supersaturated with methane may deposit gas hydrate as they pass through the diatom-rich depth interval. Results presented here are consistent with the hypothesis that gas hydrate distribution is influenced by sediment lithology and microporosity.
\end{abstract}

\section{INTRODUCTION}

Gas hydrate is a solid composed of water and certain gases (methane, $\mathrm{CO}_{2}$, propane, and ethane) that is stable under high pressure, low temperatures, and adequate concentrations of gas (Sloan, 1990; Kvenvolden, 1993). It commonly occurs in pore space of sediment on continental margins and in permafrost regions. In a number of instances, gas hydrate has been observed as a cement in sands and sandstones (Collett, 1993). Hydrate may form as cement, veins, lenses, or isolated nodules. There is considerable current interest in natural gas hydrate because it may be exploited in the near future as a source of methane (e.g., Kvenvolden, 1988; Max and Lowrie, 1996), and because methane may be released from gas hydrate to the ocean and atmosphere during oceanographic change (e.g., Hatzikiriakos and Englezos, 1994; Dickens et al., 1995).

A critical issue is to identify factors that control or limit the distribution of gas hydrate to certain depth zones in a sediment sequence. Pressure and temperature are obvious first-order constraints (e.g., Kvenvolden, 1993; Dickens and Quinby-Hunt, 1994); however, it is increasingly apparent that certain properties of the sediment surrounding gas hydrate must play important roles in controlling hydrate distribution. For example, gas hydrate in Alaskan permafrost regions and at the Middle America Trench [Deep Sea Drilling Program Leg 76] exists in discrete layers apparently related to lithology (von Huene, Aubouin, et al., 1985; Collett, 1993). At the Chile Triple Junction [Ocean Drilling Program (ODP) Leg 141], Cascadia Margin (ODP Leg 146) and Blake Ridge (ODP Leg 164), the base of gas hydrate stability exists at a depth significantly shallower than expected given pressures and temperatures at in situ conditions (e.g., Bangs et al., 1993; Kastner et al., 1995; Ruppel, 1997) and those on the methane hydrate-seawater equilibrium curve (Dickens and Quinby-Hunt, 1994).

Both experimental observations (Brewer et al., 1997) and theoretical considerations (Ruppel, 1997) suggest that the distribution of gas

'Paull, C.K., Matsumoto, R., Wallace, P.J., and Dillon, W.P. (Eds.), 2000. Proc. ODP, Sci. Results, 164: College Station, TX (Ocean Drilling Program).

${ }^{2}$ Department of Geological Sciences, University of Michigan, Ann Arbor, MI 48109-1063, U.S.A. Correspondence author (Owen): rowen@umich.edu

${ }^{3}$ School of Earth Sciences, James Cook University, Townsville, QLD 4811, Austra- hydrate is largely controlled by lithology and, in particular, the size of pore spaces between sediment grains. The rationale is that the formation of gas hydrate is inhibited in small pore spaces because the activity of water is decreased by capillary action (Handa and Stupin, 1992).

The Blake Ridge, located $350 \mathrm{~km}$ off the coast of South Carolina (Fig. 1), is a large drift deposit where laterally extensive regions contain gas hydrate (Dillon and Paull, 1983). Leg 164 crew recently drilled Sites 994, 995, and 997 on the crest of the Blake Ridge in order to refine our understanding of in situ characteristics of gas hydrate, including sediment effects on hydrate distribution (Paull, Matsumoto, Wallace, et al., 1996). Because the geology and topography on the crest of Blake Ridge is relatively simple, sediment recovered on Leg 164 provides an unprecedented opportunity to analyze basic properties of hydrated sediment and to understand variations in hydrate distribution related to lithological, chemical, and hydrological factors.

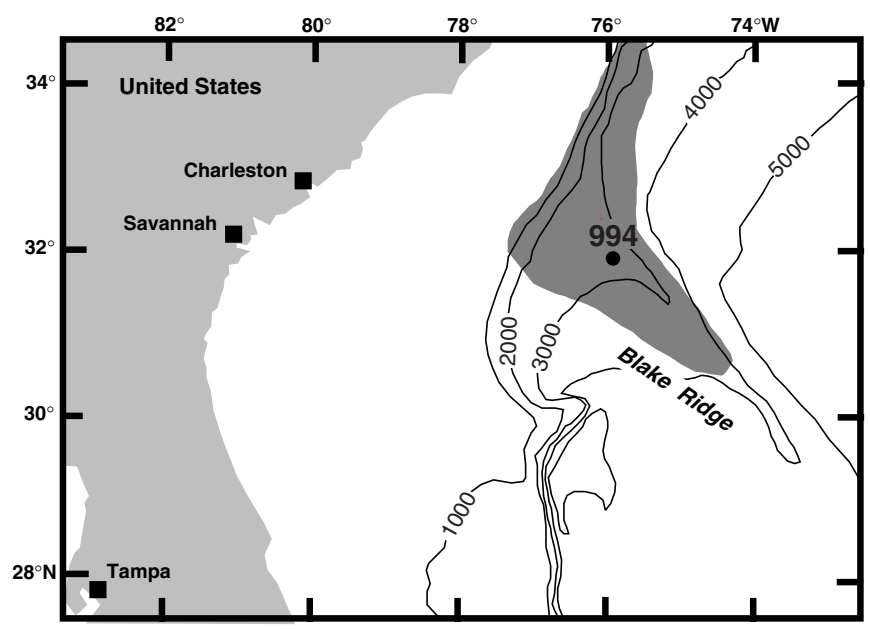

Figure 1. Location map showing Site 994 on the Blake Ridge (from Paull, Matsumoto, Wallace, et al., 1996). Shaded area is region with seismic evidence for gas hydrate and free gas. Bathymetric contours are in meters. 
A key result of Leg 164 is that gas hydrate distribution on the Blake Ridge is concentrated into a distinct upper and lower zone. Both hydrate zones are well delineated by proxy measurements for hydrate abundance (Fig. 2A, B), especially pore-water chloride concentrations (Egeberg and Dickens, unpubl. data) and pressure core sampler (PCS) gas volumes (Dickens et al., 1997). Although hydrate probably also occurs as diffuse deposits in pore spaces outside of the two zones, the two well-defined zones contain the most abundant hydrate. Both hydrate zones are well within pressure and temperature conditions for methane hydrate stability of gas-liquid systems (Dickens and Quinby-Hunt, 1994; 1997). However, whereas the abundance of hydrate in the lower zone may be explained by methane cycling across the phase boundary between free gas bubbles and gas hydrate (Hyndman and Davis, 1992; Korenaga et al., 1997), the upper zone lacks a satisfactory explanation.

Sediment layers exhibiting preferred hydrate occurrence might be linked to a relative decrease in intergranular capillary forces compared to the bulk sediment column (e.g., Clennell et al., 1995, 1997; Ruppel, 1997). The purpose of this study is to examine this hypothesis by determining if the upper hydrate zone at Site 994 is characterized by a significant change in lithology relative to underlying (and overlying) sediment. Documentation of such a lithological change, particularly one that is associated with an increase in porosity, would provide important field support for theoretical arguments concerning the influence of capillary forces on hydrate accumulation.

\section{SITE AND SAMPLE DESCRIPTIONS}

Hole 994C was drilled at 2799 meters below sea level (mbsl) to a depth of 703 meters below seafloor (mbsf). The sediment sequence is part of a large drift deposit created by deposition from the thermohaline induced Western Boundary Undercurrent (Paull, Matsumoto,

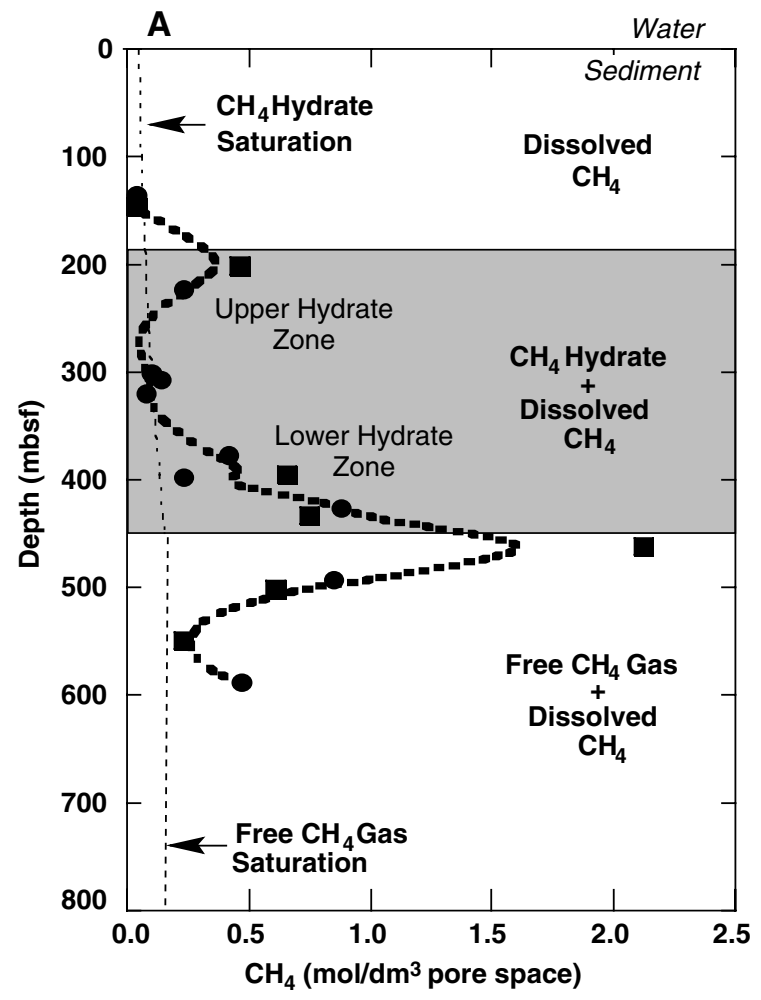

Wallace, et al., 1996). Sediments at Hole 994C were deposited from the late Miocene to the Holocene (6 to $0 \mathrm{Ma}$ ), and are dominantly composed of a mixture of terrigenous silicates and biogenic carbonates deposited by hemipelagic accumulation. Terrigenous silicates are predominantly clay with lesser amounts of quartz and feldspar; biogenic carbonates are predominantly nannofossils (coccoliths) but include foraminifers. All nannofossil zones and subzones are present without obvious hiatuses (Paull, Matsumoto, Wallace, et al., 1996). Sedimentation rates increase with depth, reaching about $400 \mathrm{~m} / \mathrm{m} . \mathrm{y}$. at the bottom of the hole (Paull, Matsumoto, Wallace, et al., 1996). Shipboard examination of smear slides indicate that clays, calcite, and quartz are the dominant mineral components; feldspars, dolomite, and pyrite are minor components. Siliceous microfossils are present primarily as diatoms (Pl. 1A, B), although there are some sponge spicules and radiolarians.

The upper zone of gas hydrate in Hole 994C exists between about 185 and $260 \mathrm{mbsf}$ (boundaries are not well defined), whereas the lower zone exists between about 380 and 450 mbsf (Paull, Matsumoto, Wallace, et al., 1996; Dickens et al., 1997). Each zone is highly heterogeneous and contains hydrate nodules, possible fracture fillings, and thin layers embedded in clay with sharp hydrate to clay boundaries (Paull, Matsumoto, Wallace et al., 1996).

One hundred and seventy-four sediment samples were taken from Hole 994C for this investigation (Table 1). Samples were taken at intervals ranging from 20 to $800 \mathrm{~cm}$ between 102 and $332 \mathrm{mbsf}$. Sampling was somewhat random because it was dictated by sample restrictions and core recovery; for example, the uneven spacing between samples is because core recovery with the extended core barrel (XCB) and depth intervals with relatively high gas concentrations was often less than 60\% (Paull, Matsumoto, Wallace, et al., 1996). Forty-nine of the samples were from within the upper hydrate zone and 125 samples were from above and below the upper hydrate zone. Samples taken were standard shipboard $10 \mathrm{~cm}^{3}$ plugs of sediment.

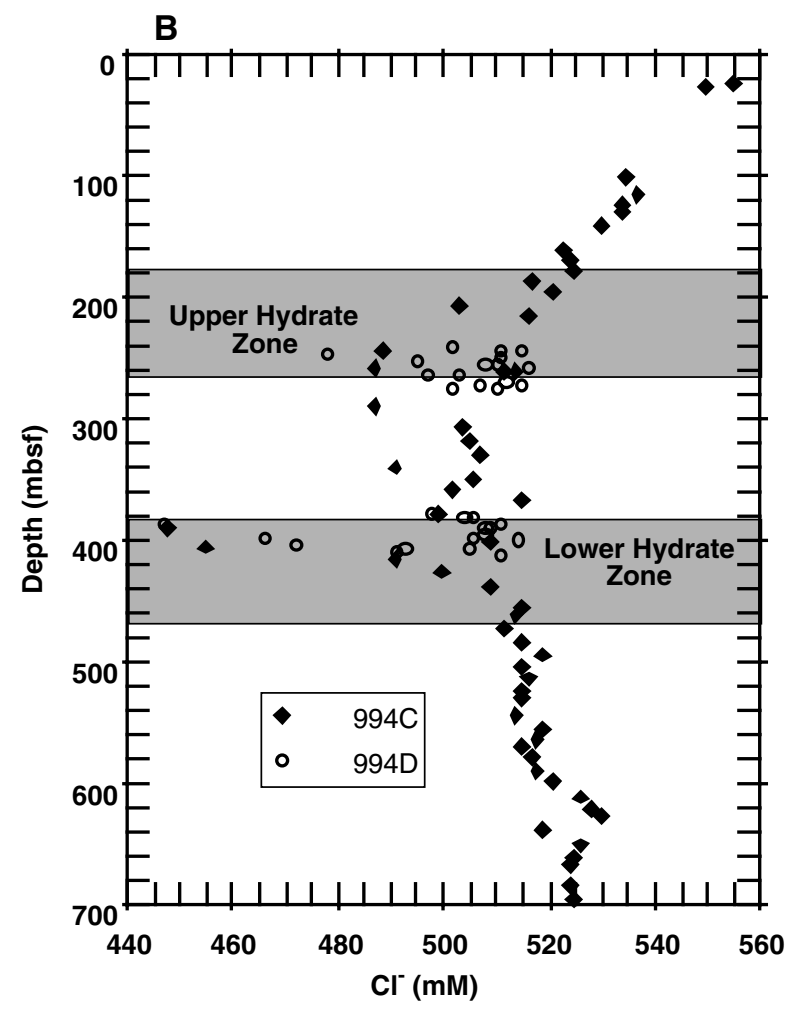

Figure 2. A. Downcore in situ gas quantities at Sites 995 (circles) and 997 (squares) (Dickens et al., 1997). B. Downcore pore-water chloride concentrations at Site 994 (Paull, Matsumoto, Wallace, et al., 1996). The independent records have been used to estimate the abundance of gas hydrate in sediment on the crest of the Blake Ridge (Paull, Matsumoto, Wallace, et al., 1996; Dickens et al., 1997). Both records show that there are two zones where gas hydrate is concentrated. 
Table 1. Chemistry and porosity of bulk sediment samples from Hole 994C.

\begin{tabular}{|c|c|c|c|c|c|c|}
\hline $\begin{array}{l}\text { Core, section, } \\
\text { interval }(\mathrm{cm})\end{array}$ & $\begin{array}{l}\text { Depth } \\
\text { (mbsf) }\end{array}$ & $\begin{array}{c}\mathrm{CaCO}_{3} \\
(\%)\end{array}$ & $\begin{array}{c}\mathrm{CaCO}_{3} * \\
(\%)\end{array}$ & $\begin{array}{c}\text { Porosity } \\
\text { (calc.) } \\
(\%)\end{array}$ & $\begin{array}{c}\text { Opal } \\
(\%)\end{array}$ & $\begin{array}{l}\text { Scandium } \\
\text { (ppm) }\end{array}$ \\
\hline 164-994C- & & & & & & \\
\hline $13 \mathrm{H}-1,142-144$ & 101.82 & & & & 6.6 & 9.7 \\
\hline $13 \mathrm{H}-3,142-144$ & 104.82 & & & & 3.5 & \\
\hline $13 \mathrm{H}-5,142-144$ & 107.82 & 23.7 & & & 4.8 & \\
\hline $13 \mathrm{H}-7,34-35^{*}$ & 109.74 & & 28.4 & & & \\
\hline $14 \mathrm{H}-1,21-23$ & 110.11 & 20.0 & & & 5.3 & 11.0 \\
\hline $14 \mathrm{H}-1,102-103 *$ & 110.92 & & 35.7 & & & \\
\hline $14 \mathrm{H}-2,21-23$ & 111.61 & 15.9 & & 63.92 & & \\
\hline $14 \mathrm{H}-2,102-103 *$ & 112.42 & & 17.2 & 60.05 & & \\
\hline $14 \mathrm{H}-3,21-23$ & 113.11 & 17.3 & & 59.36 & 5.5 & 11.9 \\
\hline $14 \mathrm{H}-4,21-23$ & 114.61 & & & 62.71 & 6.3 & 11.5 \\
\hline $14 \mathrm{H}-5,132-133 *$ & 117.22 & & 29.0 & 65.56 & & \\
\hline $14 \mathrm{H}-6,21-23$ & 117.61 & 25.6 & & 68.36 & & \\
\hline $15 \mathrm{H}-1,17-18 *$ & 119.57 & & 20.2 & 68.31 & & \\
\hline $15 \mathrm{H}-1,21-23$ & 119.61 & 19.1 & & 68.21 & & \\
\hline $15 \mathrm{H}-1,38-40$ & 119.78 & 13.9 & & 64.87 & & \\
\hline $15 \mathrm{H}-1,61-63$ & 120.10 & 13.1 & & 64.21 & & \\
\hline $15 \mathrm{H}-1,81-83$ & 120.21 & 11.6 & & 66.18 & & \\
\hline $15 \mathrm{H}-2,24-26$ & 121.14 & 13.9 & & 66.03 & & \\
\hline $15 \mathrm{H}-2,41-43$ & 121.31 & 21.1 & & 65.38 & 2.6 & \\
\hline $15 \mathrm{H}-2,58-60$ & 121.48 & 19.1 & & 64.16 & & \\
\hline $15 \mathrm{H}-2,101-103$ & 121.91 & 20.4 & & 63.74 & & \\
\hline $15 \mathrm{H}-2,121-123$ & 122.11 & 20.0 & & 60.18 & 3.3 & 12.2 \\
\hline $15 \mathrm{H}-2,141-143$ & 122.31 & 20.1 & & 59.53 & & \\
\hline $15 \mathrm{H}-3,21-23$ & 122.61 & 21.3 & & 58.88 & 2.6 & 12.2 \\
\hline $15 \mathrm{H}-3,41-43$ & 122.81 & & & 57.24 & & \\
\hline $15 \mathrm{H}-3,61-63$ & 123.01 & 25.1 & & 56.47 & 2.2 & 11.0 \\
\hline $15 \mathrm{H}-3,81-83$ & 123.21 & 23.8 & & 55.71 & 2.8 & 11.8 \\
\hline $15 \mathrm{H}-3,101-103$ & 123.41 & & & 55.30 & & \\
\hline $15 \mathrm{H}-3,121-123$ & 123.61 & 17.4 & & 55.36 & & \\
\hline $15 \mathrm{H}-3,141-143$ & 123.81 & 17.4 & & 55.42 & & \\
\hline $15 \mathrm{H}-4,21-23$ & 123.47 & 16.1 & & 55.48 & 2.8 & 12.8 \\
\hline $15 \mathrm{H}-4,41-43$ & 123.67 & 20.7 & & 55.54 & 2.9 & 11.9 \\
\hline $15 \mathrm{H}-4,57-59$ & 124.47 & 19.2 & & 55.60 & & \\
\hline $15 \mathrm{H}-4,81-83$ & 124.71 & 31.6 & & 55.66 & 2.5 & 10.5 \\
\hline $15 \mathrm{H}-4,101-103$ & 124.91 & 15.0 & & 55.56 & & \\
\hline $15 \mathrm{H}-4,121-123$ & 125.11 & & & 55.62 & & \\
\hline $15 \mathrm{H}-4,141-143$ & 125.31 & 15.8 & & 55.86 & & \\
\hline $15 \mathrm{H}-5,21-23$ & 125.61 & 18.5 & & 55.93 & 2.8 & 11.8 \\
\hline $15 \mathrm{H}-5,41-43$ & 125.81 & 22.3 & & 55.99 & & \\
\hline $15 \mathrm{H}-5,61-63$ & 126.01 & 27.4 & & 56.05 & & \\
\hline $15 \mathrm{H}-5,81-83$ & 125.57 & & & 56.11 & & \\
\hline $15 \mathrm{H}-5,121-123$ & 126.61 & 30.7 & & 56.20 & 2.9 & 11.0 \\
\hline $15 \mathrm{H}-5,141-143$ & 126.81 & & & 56.26 & & \\
\hline $15 \mathrm{H}-6,21-23$ & 127.11 & 28.9 & & 56.32 & & \\
\hline $15 \mathrm{H}-6,40-42$ & 127.30 & 28.5 & & 56.19 & & \\
\hline $15 \mathrm{H}-6,61-63$ & 127.51 & 24.4 & & 56.71 & 2.7 & 11.6 \\
\hline $15 \mathrm{H}-6,101-103$ & 127.91 & 21.8 & & 56.85 & 3.1 & 12.6 \\
\hline $15 \mathrm{H}-6,121-123$ & 128.11 & 20.1 & & 57.04 & & \\
\hline $15 \mathrm{H}-6,137-141$ & 128.27 & 20.2 & & 57.17 & 2.6 & \\
\hline $15 \mathrm{H}-7,21-23$ & 128.61 & 23.4 & & 57.31 & 2.8 & 11.4 \\
\hline $15 \mathrm{H}-7,40-42$ & 128.80 & 25.5 & & 57.57 & & \\
\hline $15 \mathrm{H}-7,63-65$ & 129.03 & 26.4 & & 57.70 & 2.2 & \\
\hline $15 \mathrm{H}-7,81-83$ & 129.21 & 21.5 & & 57.80 & 2.0 & 12.2 \\
\hline $15 \mathrm{H}-7,101-103$ & 129.41 & 27.7 & & 58.03 & 2.5 & \\
\hline $15 \mathrm{H}-7,110-111 *$ & 129.50 & & 27.6 & 58.15 & & \\
\hline $15 \mathrm{H}-7,121-123$ & 129.61 & 24.0 & & 58.30 & & \\
\hline $15 \mathrm{H}-7,141-143$ & 129.81 & 21.5 & & 56.34 & & \\
\hline $16 \mathrm{H}-2,39-41$ & 130.79 & 21.1 & & 56.15 & 2.6 & 12.4 \\
\hline $16 \mathrm{H}-2,58-59 *$ & 130.98 & & 25.2 & 56.13 & & \\
\hline $16 \mathrm{H}-4,39-41$ & 133.79 & 17.9 & & 56.10 & & \\
\hline $16 \mathrm{H}-5,39-41$ & 135.29 & 13.0 & & 56.04 & 4.3 & 12.8 \\
\hline $16 \mathrm{H}-6,39-41$ & 136.79 & 20.9 & & 55.78 & 3.6 & \\
\hline $16 \mathrm{H}-7,39-41$ & 138.29 & 18.8 & & 55.73 & 2.7 & 11.6 \\
\hline $16 \mathrm{H}-6,137-138^{*}$ & 137.77 & & 39.4 & 55.87 & & \\
\hline $17 \mathrm{H}-1,28-29 *$ & 138.68 & & 35.3 & 56.92 & & \\
\hline $17 \mathrm{H}-1,39-41$ & 138.79 & 18.4 & & 57.34 & 3.7 & 12.6 \\
\hline $17 \mathrm{H}-2,39-41$ & 140.29 & 10.0 & & 58.01 & 3.9 & 12.3 \\
\hline $17 \mathrm{H}-3,39-41$ & 141.79 & 20.6 & & 57.52 & 3.4 & 12.6 \\
\hline $17 \mathrm{H}-4,39-41$ & 143.29 & 8.3 & & 58.82 & 4.9 & 14.5 \\
\hline $17 \mathrm{H}-5,16-17 *$ & 144.56 & & 12.5 & 59.04 & & \\
\hline $17 \mathrm{H}-5,39-41$ & 144.79 & 14.4 & & 60.61 & 3.0 & 12.7 \\
\hline $17 \mathrm{H}-6,39-41$ & 146.29 & 14.1 & & 59.47 & 5.1 & 13.1 \\
\hline $17 \mathrm{H}-7,39-41$ & 147.79 & 14.1 & & 62.04 & 4.8 & 12.4 \\
\hline $19 \mathrm{H}-2,16-17 *$ & 149.27 & & 18.2 & 64.26 & & \\
\hline $19 \mathrm{H}-2,39-41$ & 149.50 & 8.7 & & 64.66 & 2.7 & 13.1 \\
\hline $19 \mathrm{H}-\mathrm{CC}, 17-18^{*}$ & 155.38 & & 17.2 & 62.80 & & \\
\hline $19 \mathrm{H}-4,39-41$ & 152.18 & 8.0 & & 59.39 & 4.5 & 13.3 \\
\hline $19 \mathrm{H}-5,39-41$ & 153.66 & 11.6 & & 60.34 & 2.7 & 13.6 \\
\hline $19 \mathrm{H}-6,39-41$ & 154.53 & 14.1 & & 60.48 & 2.6 & 13.2 \\
\hline $20 X-1,39-41$ & 158.79 & 14.0 & & 63.75 & 2.7 & 13.7 \\
\hline $20 \mathrm{X}-2,33-34 *$ & 160.23 & & 19.4 & 60.07 & & \\
\hline $20 \mathrm{X}-2,39-41$ & 160.29 & 20.1 & & 61.99 & 3.6 & 13.6 \\
\hline $20 X-3,39-41$ & 161.79 & 10.5 & & 63.33 & 3.9 & 13.7 \\
\hline $20 X-4,2-3 *$ & 162.92 & & 20.6 & 63.52 & & \\
\hline $20 X-4,39-41$ & 163.29 & 14.0 & & 62.53 & 3.1 & 13.3 \\
\hline $20 X-5,39-41$ & 164.79 & 13.8 & & 62.45 & 1.8 & 12.9 \\
\hline $21 X-1,19-21 *$ & 164.99 & & 9.9 & 60.41 & & \\
\hline $21 X-1,39-41$ & 165.19 & 8.6 & & 60.67 & 4.3 & 14.1 \\
\hline $21 X-2,39-41$ & 166.69 & 10.5 & & 60.80 & 3.1 & 13.7 \\
\hline $21 X-3,39-41$ & 168.19 & & & 61.35 & 4.7 & 12.8 \\
\hline
\end{tabular}

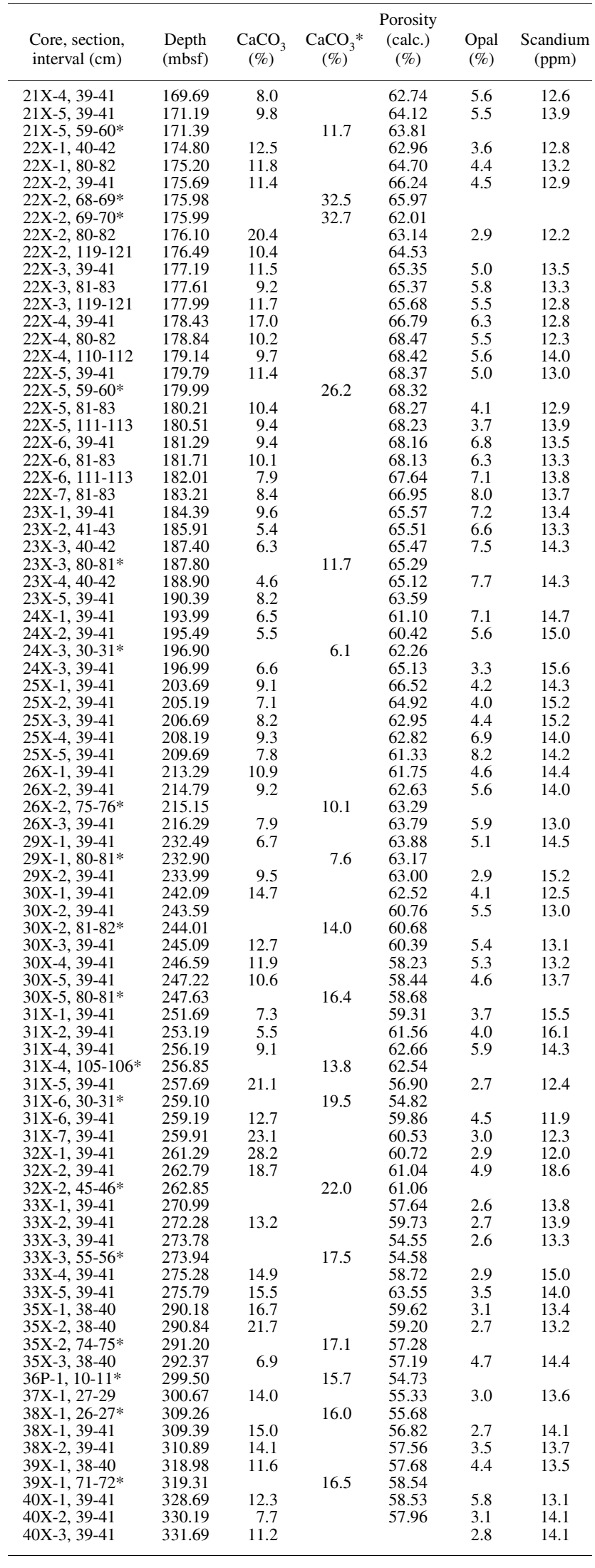

Notes: $*$ data taken from ODP database. Chemical and porosity analyses were conducted on different samples at different depths. Porosity values shown here are estimated from a best-fit curve through samples adjacent to those taken for chemical analyses. 
All samples analyzed were dark gray (5YR 4/1) to dark greenish gray (5GY 4/1 to 5Y 4/1) in color (Paull, Matsumoto, Wallace, et al., 1996).

\section{ANALYTICAL METHODS}

All 174 samples were freeze-dried and gently ground with a mortar and pestle. Three parameters of bulk sediment were then determined on some or all of the samples: (1) carbonate content, (2) biogenic silica content, and (3) scandium (Sc) concentration. Scandium concentrations were examined because $\mathrm{Sc}$ is a good proxy for the amount of aluminosilicate (clay) material in marine sediment (Schmitz et al., 1991; Dickens and Owen, 1996). Two selected samples were then examined for microstructure.

Calcium carbonate was determined using the standard carbonate bomb technique of Müller and Gastner (1971). Of the 129 samples analyzed, 35 were from within the upper hydrate zone and 94 were from above and below the zone. Each $1 \mathrm{~g}$ split of powdered sample was combined with $15 \mathrm{~mL} 3 \mathrm{~N} \mathrm{HCl}$ in a reaction vessel attached to a water filled burette. The $\mathrm{CO}_{2}$ released was measured and compared to a standard curve derived from linear regression of $\mathrm{CaCO}_{3}$ standards. A new curve was generated each day to account for variations in atmospheric pressure and room temperature. The precision of this method was within $1 \%$ to $2 \%$ as determined from known standards and replicate analyses.

Biogenic silica (opal) was determined on an atomic absorption spectrometer (AAS) with a heated graphite atomizer using a method modified from Strickland and Parsons (1968) and Eggimann et al. (1980). From a total of 110 samples, 47 were from within the upper hydrate zone and 73 were from outside the zone. About $50 \mathrm{mg}$ of a powdered sample was heated in a solution of $1 \% \mathrm{Na}_{2} \mathrm{CO}_{3}$ to leach the opal. The liquid was then diluted to within working range and analyzed for Si on the AAS. Silicon leached from clays was found to be inconsequential because the contribution from $\mathrm{Al}$ absorbance was negligible. The Si concentration was determined by comparing the absorption caused by Si to a linearly regressed standard curve derived from $25 \mathrm{~mL}$ standard solutions neutralized with $1 \mathrm{~mL}$ concentrated $\mathrm{HCl}$. Percent opal was determined stoichiometrically. Analytical precision, based on replicate analyses, was usually $\pm 5 \%$ for Si.

Scandium was determined on 101 samples by instrumental neutron activation analysis (INAA) using the nuclear reactor and counting facilities at the Phoenix Memorial Laboratory, University of Michigan. Sample preparations and analytical procedures were the same as those used by Dickens and Owen (1995), with the exception of a new data-processing system that allows higher resolution measurements. Analytical precision $(1 \sigma)$ is within $3 \%$, and total estimated errors $(1 \sigma)$ including a range of random errors is within $5 \%$. The precision and accuracy were evaluated by analyzing nine samples of NBS-SRM-679 (brick clay) in batches with Blake Ridge samples. Mean Sc concentration for the analyses of NBS-SRM-679 was 22.7 $\mathrm{ppm}$ with a standard deviation of $0.39 \mathrm{ppm}$. This compares to reported average concentrations for Sc in NBS-SRM-679 of $22.5 \mathrm{ppm}$ (Gladney et al., 1987) and $23.1 \mathrm{ppm}$ (Dickens and Owen, 1995).

Samples 164-994C-24X-1, 39-41 cm, and 164-994C-23X-4, 40$42 \mathrm{~cm}$, were impregnated with a resin/ether plastic mixture using the method developed by J. Mauk at the University of Michigan (J. Mauk, pers. comm., 1998). Samples were immersed in the plastic mixture and placed in an impregnation chamber. The chamber was then evacuated to cause the plastic to impregnate the permeable samples, and the samples were allowed to harden. The representation of in situ porosity is preserved because the sample can then be cut into thin sections without causing portions of the sample to decompose into individual grains and cause erroneous pore spaces. Thin sections were then carbon coated. A Hitachi SEM equipped with a backscatter-electron (BSE) imaging system was used to study in situ porosity and microporosity of these samples.
Porosity calculations were made from ODP bulk porosity values (Paull, Matsumoto, Wallace, et al., 1996). We fit a smooth curve through the ODP porosity data to the bottom of the hole to predict the porosity at each of the sample depths because samples are offset in depth from porosity measurements. Expected porosity is based on a log curve through all porosity data at Site 994 to account for the exponential decay of porosity because of sediment compaction. Normalized porosity (observed porosity - expected porosity) was calculated to subtract the compaction effect because there are different sediments further downcore. However, we found that normalized porosity made a negligible difference on our results.

\section{RESULTS AND DISCUSSION}

Results of our analyses are presented in Table 1. Our most important observation is that there is a distinct change in lithology across the upper hydrate zone between 185 and 260 mbsf. Calcium carbonate content of sediment averages about $25 \%$ above and below the upper hydrate zone, and about $8 \%$ within the upper hydrate zone (Fig. 3 ). Our values are similar to carbonate concentrations determined on ship (Paull, Matsumoto, Wallace, et al., 1996).

Nearly all Sc in marine sediment exists in the aluminosilicate fraction (Schmitz et al., 1991; Dickens and Owen, 1996). Therefore, scandium can be used as a first-order proxy for the amount of aluminosilicates (in this case, clay), provided the amount of Sc in the aluminosilicate fraction is known (Schmitz et al., 1991; Dickens and Owen, 1994). A value of $18 \mathrm{ppm} \mathrm{Sc}$ is used as an average of total concentration of Sc in a mixture of deep-sea clay and terrigenous shale (Gromet et al., 1984; Faure, 1991). There is a broad increase of about $10 \%$ in the clay content across the upper hydrate zone (Fig. 4), with a few peaks in clay content. This is consistent with logging results (Paull, Matsumoto, Wallace, et al., 1996).

There is also an increase in percent amorphous silica; the analytical results indicate that siliceous microfossils (as percent opal) are generally more abundant in the hydrate zone and can make up to $8 \%$

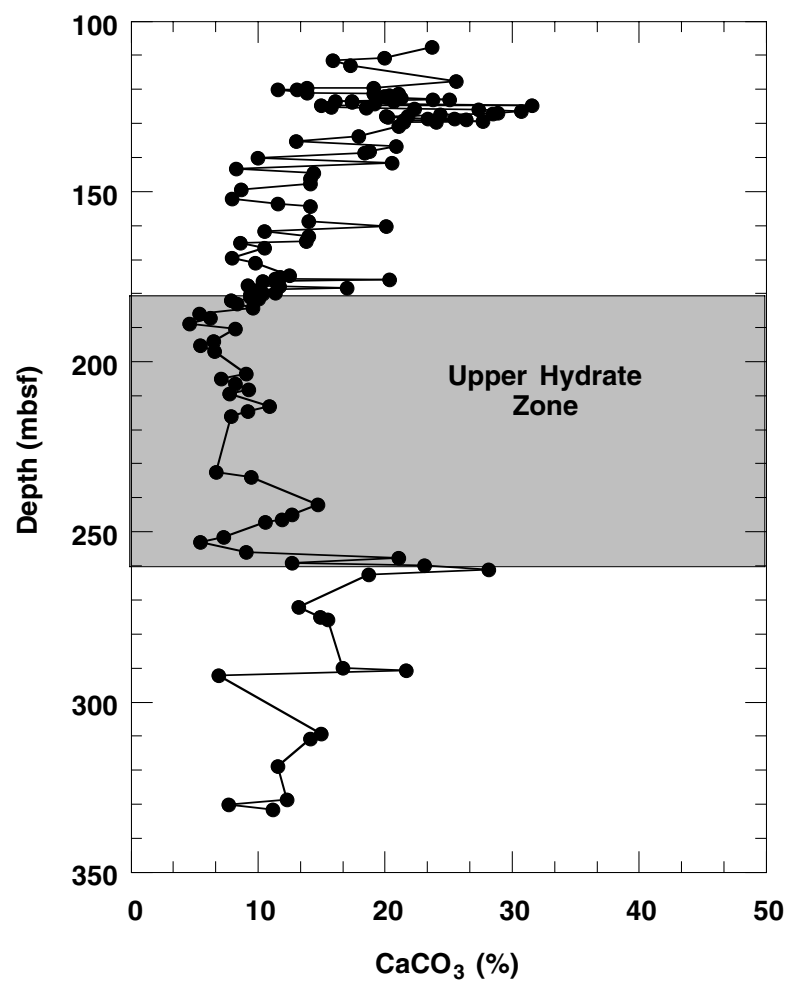

Figure 3. Downcore profile of carbonate content at Hole 994C. 


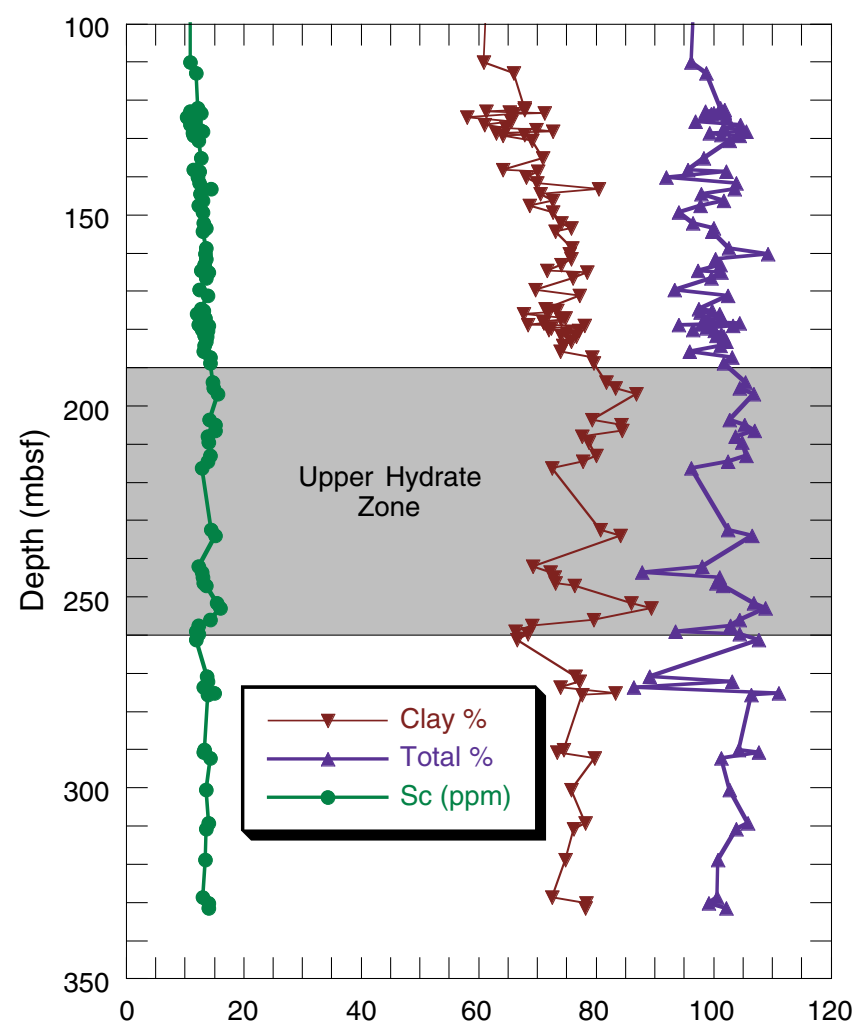

Figure 4. Downcore profiles of bulk Sc concentrations, estimated aluminosilicate (clay) content at Hole 994C, and total percentage (sum of measured opal, $\mathrm{CaCO}_{3}$, and clay percentages), and an average of $10 \%$ quartz (from Paull, Matsumoto, Wallace, et al., 1996). A Sc concentration of $18 \mathrm{ppm}$ for clay was used to convert from Sc concentration to clay content.

of the sediment (Fig. 5). Shipboard observations (Paull, Matsumoto, Wallace, et al., 1996) as well as our own (Pl. 1A, B) show this silica to be comprised mostly of diatom tests.

We do not know the abundance of quartz and other lesser components at Site 994 beyond qualitative estimates from smear slides. However, the sum of carbonate, clay (as determined from Sc), and biogenic silica is close to $90 \%$ for our samples. This is consistent with observations that there are only four major $(>5 \%)$ components in the sediment (carbonate, clay, biogenic silica, and quartz), and that the quartz content averages about 10\% (Paull, Matsumoto, Wallace, et al., 1996).

\section{Depositional Model for Shallow Hydrate on the Blake Ridge}

There is a highly significant $(\alpha<0.001)$ positive correlation between bulk porosity (from Paull, Matsumoto, Wallace et al., 1996) and percent biogenic silica (Figs. 6, 7). This indicates that an increase in percent opal results in an increase in the porosity of the sediment (Tribble et al., 1992), and that the sediment in the upper hydrate zone is significantly more porous than the surrounding sediment.

There are two ways that diatoms increase the porosity of sediment. Diatom tests folded on themselves or crushed against each other (Pl. 1B) create large (on the order of $5 \mathrm{~mm} \times 50 \mathrm{~mm}$ ) pore spaces. The microporosity of the sediment is also a factor. Pores in the diatoms are regularly about $2 \mathrm{~mm}$ in diameter (Pl. 1A, B). These openings are much larger than the pore space of surrounding sediment $(\mathrm{Pl}$. $1 \mathrm{~A}, \mathrm{~B})$.

The porosity difference between diatoms and their surrounding matrix (carbonate, clays, and quartz) may have a significant impact

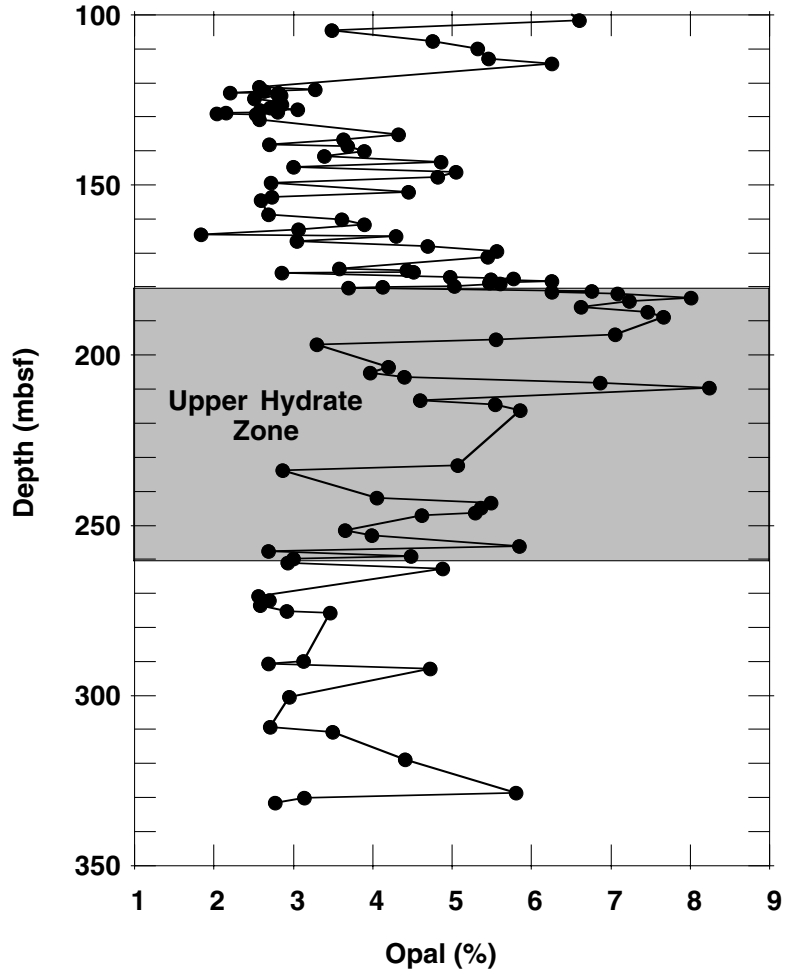

Figure 5. Downcore profile of biogenic silica (opal) content at Hole 994C.

on the formation and distribution of gas hydrate in sediment. Capillary forces between grains are inversely proportional to the radii of the menisci of interfacial water (Clennell et al., 1995; Ruppel, 1997). The menisci are between the solid methane hydrate and the unfrozen pore water, and the contact angle is effectively $180^{\circ}$. In fine-grained sediments, the menisci have extremely small radii (Klausner, 1991). This results in strong capillary forces and decreased hydrate formation in sediment dominated by carbonate and clay. However, sediment with abundant diatoms has a high number of large and round pore spaces. The presence of these openings provide nucleation sites for gas hydrate that are uninhibited by capillary forces between grains. Diatom tests should promote hydrate formation relative to the surrounding matrix.

The upper hydrate zone in sediment on the Blake Ridge can be explained by a depositional mechanism involving fluid flow and lithological change. The presence of abundant free gas bubbles below the bottom-simulating reflector (BSR) on the Blake Ridge (Dickens et al., 1997) indicates that water is supersaturated with methane at depth. Pore-water chloride profiles on the Blake Ridge are best explained by invoking significant upward advection of fluids (Egeberg and Dickens, unpubl. data). We suggest that methane-supersaturated fluids flow upward through the sediment column at Site 994. Gas hydrate is not easily precipitated in sediment dominated by clay and carbonate because hydrate cannot nucleate in the small pore spaces. However, when the supersaturated fluids encounter sediment with abundant diatoms, gas hydrate precipitates in the large and round openings between and within the diatoms. The depth interval between 260 and 380 mbsf (i.e., between the upper and lower gas hydrate zones) lacks abundant gas hydrate because there are relatively few diatom nucleation sites (Fig. 5).

The proposed depositional mechanism for gas hydrate in upper sediment on the Blake Ridge has analogs in other environments. For example, Tardy and Novikoff (1988) and Putnis et al. (1995) discussed sediment systems where precipitation of minerals from supersaturated solutions is inhibited in fine-grained sediments, but occurs in adjacent coarse-grained lithologies. 


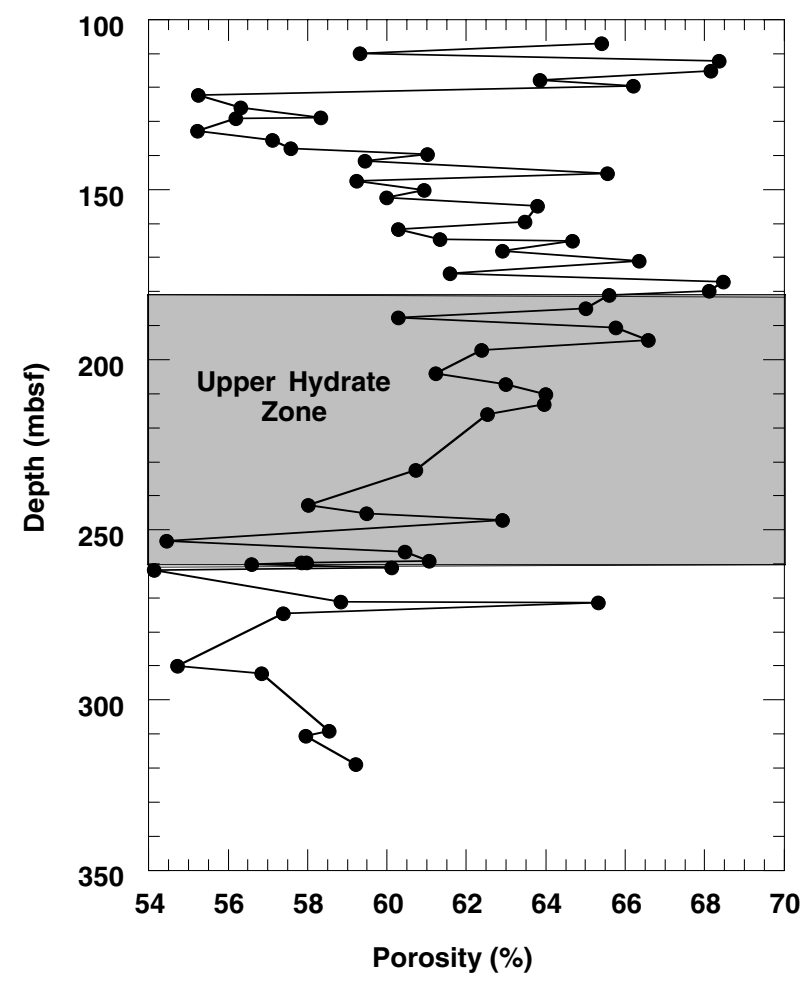

Figure 6. Downcore profile of bulk porosity data from Paull, Matsumoto, Wallace, et al. (1996).

Another recent explanation for the existence of an upper hydrate zone is the possibility that chemically distinct gas hydrates may be stable in different burial depths (Kastner et al., 1998). However, evidence indicates that Hole 994C hydrate is chemically homogenous and contains only Structure I hydrate (with only trace amounts of propane). Consequently, the hydrate at Site 994 should not be vertically heterogeneous because of chemical variations.

\section{Origin of the Diatom Zone}

The Blake Ridge is a contourite deposit created by sediment deposition from the thermohaline-induced Western Boundary Undercurrent (Shipboard Scientific Party, 1972). Primary deposition is by hemipelagic accumulation of terrigenous and biogenic components as well as by biogenic tests sinking from surface water. This deposition is then modified through reworking and redeposition of sediment by contour currents of varying intensity (Pinet et al., 1981; Paull, Matsumoto, Wallace, et al., 1996). Lithologic variations at Site 994 may be caused by fluctuations in bottom-current intensity, terrigenous output, or carbonate and biogenic silica productivity.

The diatom-rich interval at Site 994 was deposited during the late Pliocene (between about 3.5 and 2.7 Ma) (Paull, Matsumoto, Wallace, et al., 1996). This corresponds to a time of global warming and an acceleration of thermohaline circulation, especially in the North Atlantic. Several locations from around the world show an increase in diatom abundance at this time interval, presumably because the change in oceanic circulation led to elevated nutrient fluxes in multiple regions (e.g., Dickens and Owen, 1996). We speculate that the increased abundance of diatoms at Site 994 is causally linked to the change in oceanographic conditions and surficial productivity rather than some local effect on sedimentation. The diatom-rich interval observed at Site 994 may, therefore, extend over a large area. Gas hy-

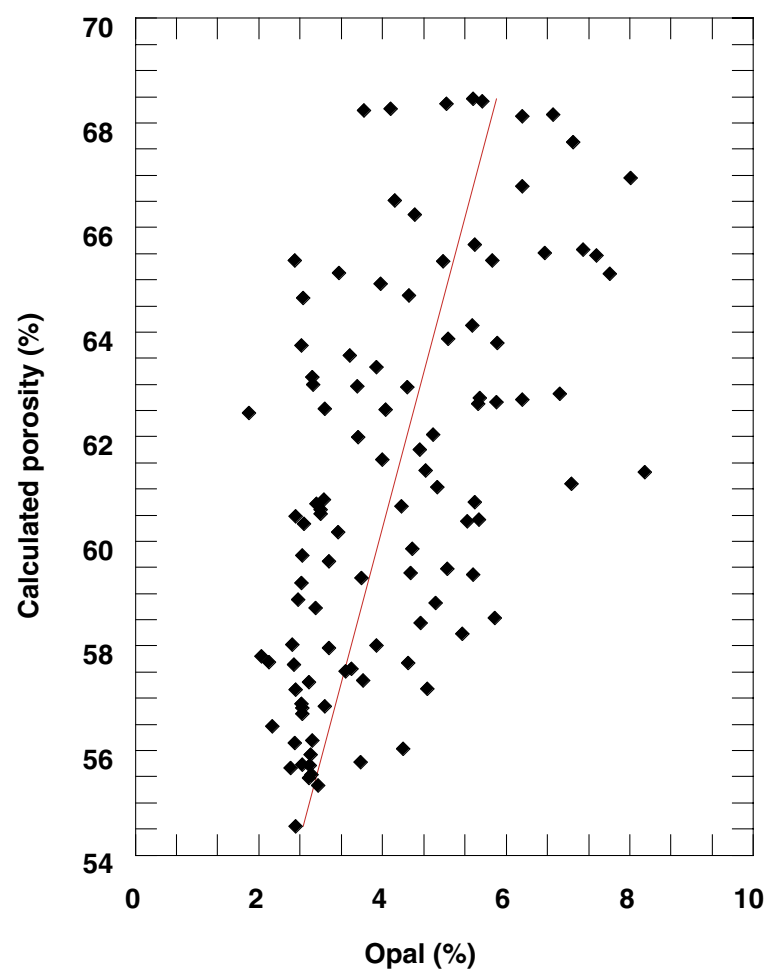

Figure 7. The relationship between biogenic silica (opal) content and bulk porosity at Hole 994C. Porosity values are not at the same depth as our samples but were extrapolated from adjacent shipboard values using a best fit curve. A highly significant $(\alpha<0.001)$ positive correlation exists between the two sediment parameters.

drate amounts may be higher than expected wherever this unit exists on the Blake Ridge; that is, the upper hydrate zone at Site 994 may be a regional phenomenon (although it would occur at different depths depending on sedimentation rate).

\section{SUMMARY AND CONCLUSIONS}

The distribution of hydrate at Site 994, Leg 164, is highly heterogeneous. Gas hydrate in this region occurs in the sediment column between $\sim 180-450$ mbsf. However, the hydrate is mainly concentrated in two depth zones: between 185 and 260 mbsf and between 380 and $450 \mathrm{mbsf}$. The lower hydrate zone can be explained by methane cycling across the phase boundary between free gas bubbles and gas hydrate. The upper zone can now be attributed to a change in lithology, porosity, and, consequently, a change in the ease of formation of methane hydrate.

Chemical analyses of sediment samples indicate a distinct change in lithology in the upper hydrate zone. The $\mathrm{CaCO}_{3}$ content of sediment above and below the hydrate zone is $\sim 25 \%$, as opposed to $\sim 8 \%$ within the hydrate zone. Siliceous microfossils increase in abundance, and there is a resulting increase in porosity. An increase in the abundance of siliceous microfossils may (1) decrease the capillary forces between grains and decrease inhibition of hydrate formation, and (2) change the sediment pore shapes and sizes and increase hydrate ease of formation as a result of the large clathrate cage size. Our results from Site 994 are consistent with recent suggestions that the precipitation of gas hydrate in a sediment matrix is related to the size of the pore space in which the hydrate crystal grows (Klausner, 1991; 
Handa and Stupin, 1992; Clennell et al., 1995; Claypool, 1996; Brewer et al., 1997; Ruppel, 1997). However, it must be noted that sediment permeability plays a significant role in gas hydrate development, and that variations in permeability may also lead to zones of hydrate accumulation.

\section{ACKNOWLEDGMENTS}

We sincerely thank A. Ribbens, the JOIDES Resolution crew, and other members of the Leg 164 scientific party for a successful cruise. We thank B. Clennell, C. Ruppel, and G. Claypool for sharing their unpublished ideas on capillary pressures and stimulating this research. This work was funded by the NSF through a JOI-USSAC grant (\#F000266) to R. Owen, and through the JCU-MRG program for G. Dickens.

\section{REFERENCES}

Bangs, N.L.B., Sawyer, D.S., and Golovchenko, X., 1993. Free gas at the base of the gas hydrate zone in the vicinity of the Chile triple junction. Geology, 21:905-908.

Brewer, P.G., Orr, F.M., Jr., Friederich, G., Kvenvolden, K.A., Orange, D.L., McFarlane, J., and Kirkwood, W., 1997. Deep-ocean field test of methane hydrate formation from a remotely operated vehicle. Geology, 25:407-410.

Claypool, G.E., 1996. Influence of water solubility, phase equilibria, and capillary pressure on methane occurrence in sediments. AAPG Ann. Meeting, 5:27. (Abstract)

Clennell, M.B., Henry, P., Thomas, M., Booth, J.S., Winters, B., and Hovland, M., 1997. Stability and growth of natural gas hydrates in marine sediments: concepts and calculations. Eos, 78:343.

Clennell, M.B., Hovland, M., Lysne, D., and Booth, J.S., 1995. Role of capillary forces, coupled flows and sediment-water depletion in the habitat of gas hydrate. Eos, 76:164-165.

Collett, T.S., 1993. Natural gas hydrates of the Prudhoe Bay-Kuparuk River area, North Slope, Alaska. AAPG Bull., 77:793-812.

Dickens, G.R., O'Neil, J.R., Rea, D.K., and Owen, R.M., 1995. Dissociation of oceanic methane hydrate as a cause of the carbon isotope excursion at the end of the Paleocene. Paleoceanography, 10:965-971.

Dickens, G.R., and Owen, R.M., 1994. Late Miocene-early Pliocene manganese redirection in the central Indian Ocean: expansion of the intermediate water oxygen minimum zone. Paleoceanography, 9:169-181.

, 1995. Chinook Trough rifting and hydrothermal deposition at Sites 885 and 886. In Rea, D.K., Basov, I.A., Scholl, D.W., and Allan, J.F. (Eds.), Proc. ODP, Sci. Results, 145: College Station, TX (Ocean Drilling Program), 413-426.

1996. Sediment geochemical evidence for an early-middle Gilbert (early Pliocene) productivity peak in the North Pacific Red Clay Province. Mar. Micropaleontol., 27:107-120.

Dickens, G.R., Paull, C.K., Wallace, P., and the ODP Leg 164 Scientific Party, 1997. Direct measurement of in situ methane quantities in a large gas-hydrate reservoir. Nature, 385:427-428.

Dickens, G.R., and Quinby-Hunt, M.S., 1994. Methane hydrate stability in seawater. Geophys. Res. Lett., 21:2115-2118.

1997. Methane hydrate stability in pore water: a simple theoretical approach for geophysical applications. J. Geophys. Res., 102:773783

Dillon, W.P., and Paull, C.K., 1983. Marine gas hydrates, II. Geophysical evidence. In Cox, J.L. (Ed.), Natural Gas Hydrates: Properties, Occurrences, and Recovery: Woburn, MA (Butterworth), 73-90.

Eggimann, D.W., Manheim, F.T., and Betzer, P.R., 1980. Dissolution and analysis of amorphous silica in marine sediments. J. Sediment. Petrol., $50: 215-225$.

Faure, G., 1991. Principles and Applications of Inorganic Geochemistry: New York (Macmillan).

Gladney, E.S., O'Malley, B.T., Roelandts, I., and Gills, T.E., 1987. Standard reference materials: compilation of elemental concentration data for NBS clinical, biological geological, and environmental standard reference materials. NBS Spec. Publ. (U.S.), 260-111.
Gromet, L.P., Dymek, R.F., Haskin, L.A., and Korotev, R.L., 1984. The "North American Shale Composite:" its compilation, major and trace element characteristics. Geochim. Cosmochim. Acta, 48:2469-2482.

Handa, Y.P., and Stupin, D., 1992. Thermodynamic properties and dissociation characteristics of methane and propane hydrates in 70 - $\AA$-radius silica-gel pores. J. Phys. Chem., 96:8599-8603.

Hatzikiriakos, S.G., and Englezos, P., 1994. Permafrost melting and stability of offshore methane hydrates subject to global warming. Internat. J. Offshore Polar Eng., 4:162-166.

Hyndman, R.D., and Davis, E.E., 1992. A mechanism for the formation of methane hydrate and seafloor bottom-simulating reflectors by vertical fluid expulsion. J. Geophys. Res., 97:7025-7041.

Kastner, M., Kvenvolden, K.A., and Lorenson, T.D., 1998. Chemistry, isotopic composition, and origin of a methane-hydrogen sulfide hydrate at the Cascadia subduction zone. Earth Planet. Sci. Lett., 156:173-183.

Kastner, M., Kvenvolden, K.A., Whiticar, M.J., Camerlenghi, A., and Lorenson, T.D., 1995. Relation between pore fluid chemistry and gas hydrates associated with bottom-simulating reflectors at the Cascadia Margin, Sites 889 and 892. In Carson, B., Westbrook, G.K., Musgrave, R.J., and Suess, E. (Eds.), Proc. ODP, Sci. Results, 146 (Pt 1): College Station, TX (Ocean Drilling Program), 175-187.

Klausner, Y., 1991. Fundamentals of Continuum Mechanics of Soils: London (Springer-Verlag).

Korenaga, J., Holbrook, W.S., Singh, S.C., and Minshull, T.A., 1997. Natural gas hydrates on the southeast U.S. margin: constraints from full waveform traveltime inversions of wide-angle seismic data. J. Geophys. Res., 102:15345-15365.

Kvenvolden, K.A., 1988. Methane hydrate-a major reservoir of carbon in the shallow geosphere? Chem. Geol., 71:41-51.

, 1993. Gas hydrates: geological perspective and global change. Rev. Geophys., 31:173-187.

Max, M.D., and Lowrie, A., 1996. Oceanic methane hydrates: a "frontier" gas resource. J. Pet. Geol., 19:41-56.

Müller, G., and Gastner, M., 1971. The "Karbonat-Bombe", a simple device for the determination of the carbonate content in sediments, soils and other materials. Neues. Jahrb. Mineral. Monatsh., 10:466-469.

Paull, C.K., Matsumoto, R., Wallace, P.J., et al., 1996. Proc. ODP, Init. Repts., 164: College Station, TX (Ocean Drilling Program).

Pinet, P.R., Popenoe, P., and Nelligan, D.F., 1981. Gulf stream: reconstruction of Cenozoic flow patterns over the Blake plateau. Geology, 9:266270.

Putnis, A., Prieto, M., and Fernandez-Diaz, L., 1995. Fluid supersaturation and crystallization in porous media. Geol. Mag., 132:1-13.

Ruppel, C., 1997. Anomalously cold temperatures observed at the base of the gas hydrate stability zone on the U.S. Atlantic passive margin. Geology, 25:699-702.

Schmitz, B., Asaro, F., Michel, H.V., Thierstein, H.R., and Huber, B.T., 1991. Element stratigraphy across the Cretaceous/Tertiary boundary in Hole 738C. In Barron, J., Larsen, B., et al., Proc. ODP, Sci. Results, 119: College Station, TX (Ocean Drilling Program), 719-730.

Shipboard Scientific Party, 1972. Sites 102-103-104-Blake-Bahama Outer Ridge (northern end). In Hollister, C.D., Ewing, J.I., et al., Init. Repts. DSDP, 11: Washington (U.S. Govt. Printing Office), 135-218.

Sloan, E.D., 1990. Clathrate Hydrates of Natural Gases: New York (Marcel Dekker).

Strickland, J.D.H., and Parsons, T.R., 1968. A manual for seawater analysis. Bull. Fish. Res. Bd. Can., 167:311.

Tardy, Y., and Novikoff, A., 1988. Activité de l'eau et déplacement des équilibres gibbsite-kaolinite dans les profils latéritiques. C. R. Acad. Sci. Ser. 2, 306:39-44.

Tribble, J.S., Mackenzie, F.T., Urmos, J., O'Brien, D.K., and Manghnani, M.H., 1992. Effects of biogenic silica on acoustic and physical properties of clay-rich marine sediments. AAPG Bull., 76:792-804.

von Huene, R., Aubouin, J., et al., 1985. Init. Repts. DSDP, 84: Washington (U.S. Govt. Printing Office).

Date of initial receipt: 21 April 1998

Date of acceptance: 16 September 1998

Ms 164SR-221 


\section{A}

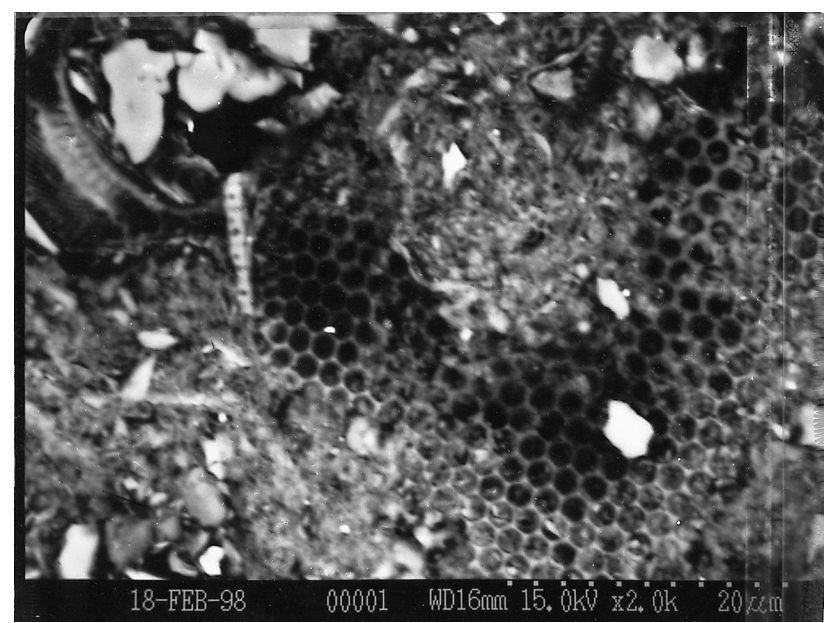

B

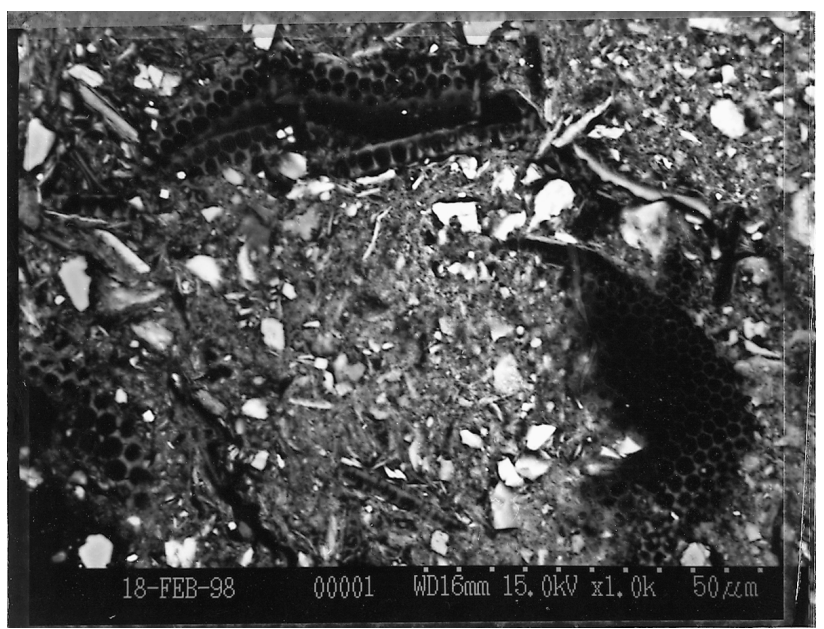

Plate 1. Samples are in thin sections impregnated with plastic so that in situ porosity can be observed. A. Diatom ( 40 mm in diameter) in sediment from the upper hydrate zone at Site 994C, Blake Ridge (Sample 164-994C-24X-1, 39-41 cm). B. Several diatoms in upper hydrate zone at Site 994C, Blake Ridge (Sample 164-994C-23X-4, 40-42 cm). Upper-left diatom(s) was crushed (naturally) and a large pore space (50 mm long by $5 \mathrm{~mm}$ wide) is observed. 